\title{
33. ORGANIC GEOCHEMISTRY OF CRETACEOUS BLACK SHALES AND ADJACENT STRATA FROM THE GALICIA MARGIN, NORTH ATLANTIC OCEAN1
}

\author{
Keith W. Dunham, Philip A. Meyers, and Eileen S. Ho, Oceanography Program, Department of Geological \\ Sciences, The University of Michigan, Ann Arbor, Michigan
}

\begin{abstract}
Organic-carbon-rich "black shales" and adjacent organic-carbon-poor rocks from three different Cretaceous settings encountered during ODP Leg 103 have been studied by organic geochemical methods. Rock-Eval analysis, carbon isotope data, and lipid biomarkers show organic matter to contain varying proportions of marine and continental materials. In Hauterivian-Barremian organic-carbon-rich marlstone turbidites, large amounts of land-derived organic matter are found. Aptian-Albian black-colored shales are interspersed within green claystones, from which they differ by containing more marine organic matter. An abbreviated layer of black shale from the Cenomanian/Turonian boundary is dominated by well-preserved marine organic matter. Downslope transport and rapid reburial within a predominantly oxygenated deep-water setting created most of these examples of black shales, except for the Cenomanian-Turonian deposits in which deep-water anoxia may have been involved.
\end{abstract}

\section{INTRODUCTION}

Organic-carbon-rich strata in Cretaceous sequences have been described from many Deep Sea Drilling Project (DSDP) sites in the North Atlantic Ocean. Although their individual lithologies often vary, these "black shales" share the traits of being darker in color and richer in organic matter than typical deep-ocean sediments and sedimentary rocks. In general, organic carbon contents of black shales are above $1 \mathrm{wt} \%$ and reach up to 30 wt \% (Weissert, 1981), whereas the typical content of DSDP samples is on the order of $0.2 \mathrm{wt} \%$ (McIver, 1975). Because the amounts and types of organic matter buried in sediments are influenced both by the oceanographic and depositional conditions existing at the time of sedimentation and by subsequent postdepositional processes, study of the organic constituents of black shales can provide information about the many factors involved in their formation. Reviews of organic geochemical studies of Cretaceous black shales (e.g., Arthur et al., 1984; Stein et al., 1986; Simoneit, 1986) have pointed out that both marine and continental sources have contributed organic matter to these facies and that various paleoenvironmental situations have led to their accumulation. In this chapter, we compare the organic geochemical characteristics of black shales found during Ocean Drilling Program (ODP) Leg 103 in sequences deposited during three intervals of Cretaceous time on the Galicia margin to those of interbedded organic-carbon-lean rocks, and we consider the possible paleoceanographic conditions that may have caused these episodes of black shale deposition.

\section{LITHOLOGIC SETTING}

Drilling during Leg 103 was done at five sites on the Galicia margin (Fig. 1) to obtain samples of sedimentary rocks that record the history of the eastern North Atlantic from the early stages of subsidence and rifting, through spreading of this ocean, to near-modern conditions. The results from the five sites have been combined to form a composite lithostratigraphic column (Boillot et al., 1985) illustrating that the lithologic units common to most of the North Atlantic seafloor (Jansa et al., 1978) also exist on the margin of the Iberian Peninsula. These units

${ }^{1}$ Boillot, G., Winterer, E. L., et al., 1988. Proc. ODP, Sci. Results, 103: College Station, TX (Ocean Drilling Program). have been described best in the western North Atlantic, and their names are based upon their occurrences there (Jansa et al., 1979). Although application of these names may not be entirely appropriate for the rock units present in the eastern Atlantic, it is useful to describe the units found at the Leg 103 sites in terms of the corresponding western Atlantic units to stress the very real similarities between coeval rocks deposited on both sides of this ocean.

A thick limestone, marlstone, and sandstone sequence corresponding to the Blake-Bahama Formation was deposited on the Galicia margin from the Tithonian to Barremian. This deposition was followed by accumulation of debris flows and turbidites and subsequently bioturbated claystones that contain interspersed black shales. This latter unit, corresponding to the Hatteras Formation, extends from Aptian to Cenomanian strata.

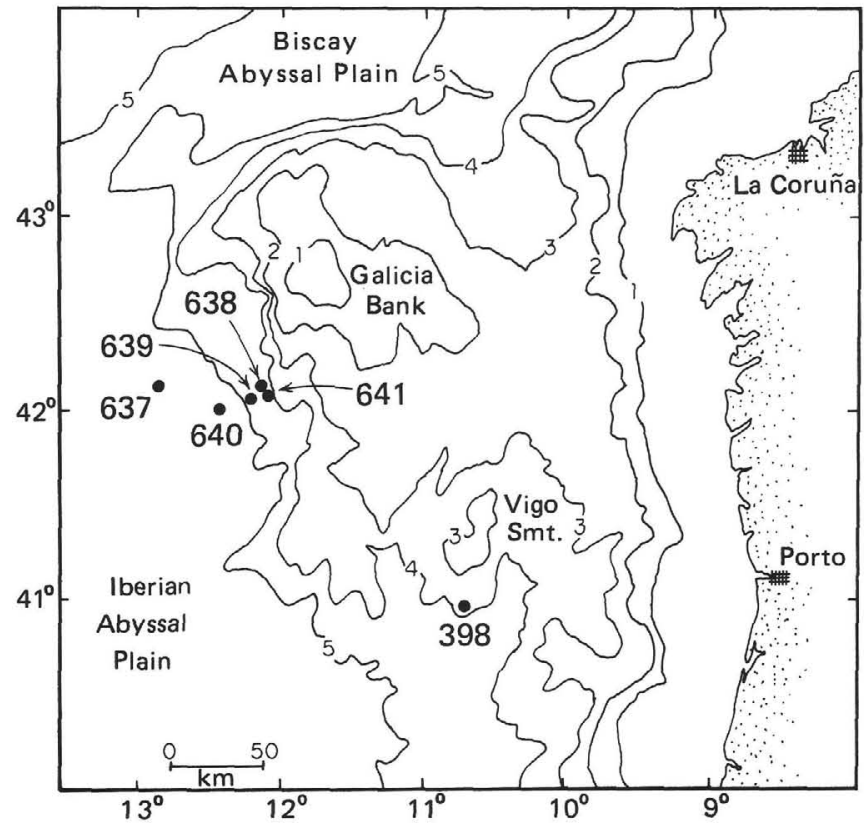

Figure 1. Locations of ODP Leg 103 sites and DSDP Site 398. Depth contours are in kilometers. 
Drilling during Leg 103 concentrated on older objectives, and hence, full sections of strata younger than middle Cretaceous were not recovered. Some younger samples, however, were obtained and are also described in this report.

\section{Methods}

Two groups of samples were collected during Leg 103 for the purpose of this study. The first group consists of 61 smaller samples selected from representative lithologies found in coring each of the five sites occupied during this leg. These samples provided a general background from which the second group of 13 larger samples was selected for detailed organic geochemical analyses.

Measurements of contents of calcium carbonate and of organic carbon were made on the group of smaller samples using the shipboard Coulometrics carbonate analyzer and Perkin-Elmer 240C CHN analyzer (Emeis and Kvenvolden, 1986). In addition, Rock-Eval pyrolysis was done on many of these samples using the shipboard Delsi instrument. Onshore determination of the stable carbon isotope ratios of the organic carbon of these samples was done using a VG Micromass 602 mass spectrometer calibrated with NBS-20 (carbonate) and NBS-21 (graphite) standards. Data are corrected for ${ }^{17} \mathrm{O}$ and are presented relative to the PDB standard.

The larger samples selected for detailed analysis of their organic matter contents, which are relatively labile to microbial attack and alteration, were frozen upon collection and kept frozen until analyses began. These samples were freeze-dried as the first step in their study. Calcium carbonate contents were determined by the carbonate bomb technique (Müller and Gastner, 1971). Measurements of residual carbon with a Hewlett-Packard 185B CHN analyzer after $\mathrm{HCl}$ dissolution of carbonates was considered to represent the total organic carbon content. Organic matter atomic $\mathrm{C} / \mathrm{N}$ ratios were determined from residual carbon values. Organic carbon concentrations of the samples were calculated on a dry-weight basis for the original, carbonate-containing rock. Stable carbon isotope ratios of the organic carbon were determined as previously described for the smaller samples.

As part of the detailed analysis, lipids were obtained from samples of freeze-dried sediment by Soxhlet extraction with toluene/methanol for $24 \mathrm{hr}$. These lipids are called "free" in this report, but no implications about the presence or absence of chemical bonds are intended. After being concentrated, lipid extracts were saponified and then methylated with methanolic boron trifluoride, as described by Leenheer et al. (1984).

Column chromatography of each sample on a column packed with aluminum oxide over silica gel, as detailed by Leenheer et al. (1984), provided three fractions: hydrocarbons (saturated plus aromatic), fatty acid methyl esters, and a sterol-alcohol fraction. The sterol-alcohol fractions were derivatized with BSTFA. An internal standard of $5 \alpha$-cholestane was added to each fraction for quantification by gas chromatography.

Hydrocarbon, fatty acid methyl ester, and fatty alcohol ether fractions were analyzed using a Hewlett-Packard 5830A FID gas chromatograph equipped with a $20-\mathrm{m} \mathrm{SE}-54$ capillary column and fitted with a splitless injection system. Hydrogen was used as the carrier gas and nitrogen as the makeup gas. Quantitative results were obtained using the internal standard amounts after corrections were made with response factors calculated from standard mixes. The reported results have been further corrected for small amounts of laboratory contamination as determined from blank analyses.

\section{RESULTS AND DISCUSSION}

\section{Organic Carbon and Organic Matter C/N Ratios}

Compilation of the general geochemical characteristics of the 74 samples of sediments and rocks examined in this study shows that many of the samples are very low in organic carbon concentrations (Table 1). Neogene and Quaternary sediments have values close to the average of $0.2 \mathrm{wt} \%$ obtained by Mclver (1975) from data from DSDP Legs 1 through 33, but older rocks commonly have concentrations lower than this average. Because sampling of Cretaceous rocks was biased toward black shales and adjacent strata, organic carbon concentrations are generally significantly higher in Lower and Upper Cretaceous samples than the 0.2 wt $\%$ average compiled by McIver (1975). Neo- comian limestones and marlstones have concentrations ranging from 0.05 to $4.85 \mathrm{wt} \%$ (Table 1); this sequence is equivalent in lithology and overall organic matter characteristics to the BlakeBahama Formation of the western North Atlantic. Aptian-Albian claystones are somewhat higher in organic carbon content than the older carbonate sequence, having values generally between 0.15 and $4.90 \mathrm{wt} \%$. Sample $103-641 \mathrm{C}-3 \mathrm{R}-5,55-56 \mathrm{~cm}$, is enriched by woody fragments to $19.74 \mathrm{wt} \%$ organic carbon. An abbreviated sequence of green and black claystones was obtained in Hole 641A at the Cenomanian/Turonian boundary. Organic carbon concentrations are between 0.11 and 1.94 wt \% in the green claystones and reach elevated values of 10.34 to $12.78 \mathrm{wt} \%$ in black shales within this short sequence. The combination of Aptian to Cenomanian predominantly green and black claystones is equivalent to the Hatteras Formation. Younger strata contain no black shales and are consistently poor in organic carbon.

Atomic $\mathrm{C} / \mathrm{N}$ ratios of organic matter were determined on only 12 of the 74 samples, yet these limited data show several important distinctions among the various lithologic types (Table 1). Carbonate-rich Neocomian rocks have relatively high $\mathrm{C} / \mathrm{N}$ values, between 30 and 76, regardless of organic carbon contents. In contrast, Albian and Cenomanian claystones have $\mathrm{C} / \mathrm{N}$ ratios related to their organic carbon concentrations. Organiccarbon-rich black shales have an average value of 18 , whereas organic-carbon-poor green claystones have values averaging 8 . These differences parallel those found in equivalent lithologies at DSDP Site 603 on the outer Hatteras Rise (Dunham et al., 1987). At both of these locations, the high $\mathrm{C} / \mathrm{N}$ values in Neocomian samples suggest that land-derived organic matter is an important constituent in the black shales in the Blake-Bahama Formation, whereas the lower $\mathrm{C} / \mathrm{N}$ values of Albian and Cenomanian samples indicate that a larger proportion of marine-derived organic matter is present in the Hatteras Formation black shales (cf. Dunham et al., 1987).

\section{Carbon Isotope and Rock-Eval Analyses}

Sources of the organic matter found in sedimentary rocks can be indicated by carbon stable isotope ratios and by RockEval pyrolysis data. In modern sediments, land-derived organic matter is generally more depleted in ${ }^{13} \mathrm{C}$ than marine organic matter is. In general, continental C-3 plants synthesize organic matter having $\delta^{13} \mathrm{C}$ values ranging between $-23 \%$ and $-33 \%$, whereas organic matter produced by most marine plankton has values between $-17 \%$ and $-23 \%$ (Gaskell et al., 1975; Anderson and Arthur, 1983; Peterson et al., 1985). The organic matter $\delta^{13} \mathrm{C}$ record in sediments can be significantly influenced, however, by bacterial reworking, diagenesis, and changes in the availability of carbon to photosynthetic organisms (e.g., Anderson and Arthur, 1983; Dean et al., 1986). Because of the possibility of shifts in the carbon isotopic signature being caused by other than source changes, additional organic matter parameters should be considered when attempting paleoenvironmental reconstructions.

Carbon isotope ratios of Leg 103 samples, expressed in the conventional $\delta^{13} \mathrm{C}$ notation in Table 1 , range between $-23.0 \%$ o and $-28.5 \%$, which is not a broad variation considering the considerable contrasts in sample ages and lithologic types. A weak trend toward heavier, more marine isotopic compositions exists in younger samples. The two Tithonian samples have $\delta^{13} \mathrm{C}$ values around $-25.2 \%$, whereas $-24.0 \%$ is the mean of the five Pleistocene samples. The excursion in carbon isotope ratios, in which Cretaceous rocks richer in marine organic matter have lighter $\delta^{13} \mathrm{C}$ values than those found in modern marine organic carbon (Dean et al., 1986), is not strongly developed in these eastern North Atlantic samples. In this regard, the Leg $103 \delta^{13} \mathrm{C}$ data resemble those of rocks from DSDP Sites 398 and 
Table 1. Descriptions of sediments and rocks surveyed in this study and their general organic geochemical characteristics.

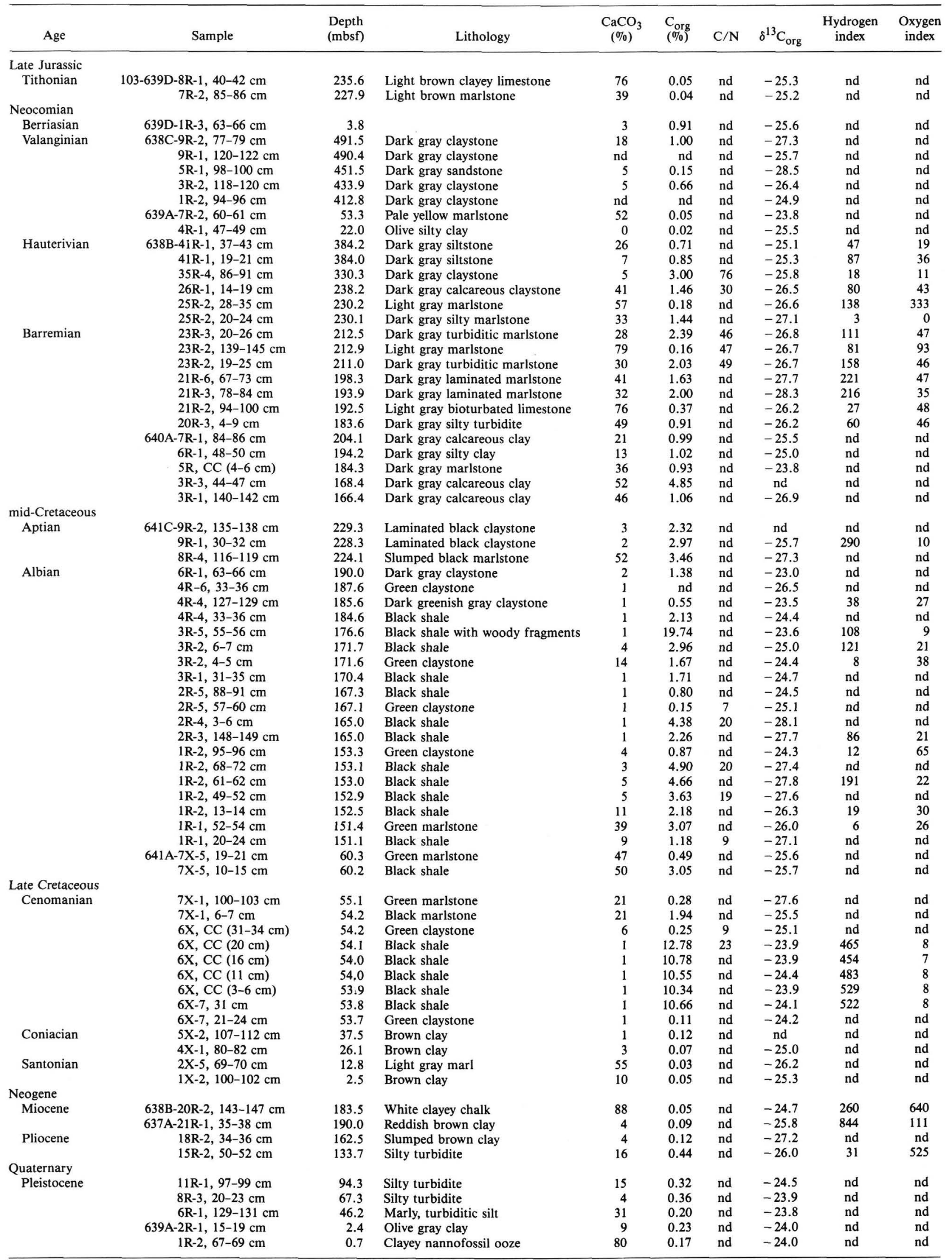

Note: $\mathrm{nd}=$ not determined. 
402, which are also in the eastern North Atlantic Ocean (Erdman and Schorno, 1979a, 1979b).

Little difference in isotopic content is present between rocks rich or poor in organic matter. Using the arbitrary value of $1 \%$ organic carbon to distinguish between these two classifications, 10 Neocomian samples rich in organic matter have a mean $\delta^{13} \mathrm{C}$ value of $-26.8 \% \pm 0.9 \%$; the 14 related lean samples have $-25.7 \% 0 \pm 1.2 \% 0$ as their mean. Sixteen rich Aptian-Albian samples average $-26.1 \% 0 \pm 1.5 \%$, whereas their five lean counterparts average $-24.6 \% 0 \pm 0.8 \%$. The short Cenomanian section yielded six samples rich in carbon, having a mean $\delta^{13} \mathrm{C}$ value of $-24.3 \%$ $\pm 0.6 \%$; the three samples poor in carbon averaged $-25.6 \% \pm \pm 1.8 \%$. Because most of these isotopic values fall midway between the $\delta^{13} \mathrm{C}$ ratios of $-21 \% 0 \pm 1 \%$ and $-29 \% 0 \pm 1 \%$ reported by Peterson et al. (1985) for modern marine plankton and modern C-3 land plants, respectively, they are not particularly diagnostic as source indicators, suggesting only a mixture of marine and continental material in this ocean margin setting.

Rock-Eval pyrolysis is intended for rocks having organic matter that is more thermally mature and at somewhat higher concentrations than is commonly found at ODP sites. Nonetheless, Rock-Eval data have been useful in helping to characterize organic matter sources and maturity in DSDP and ODP samples. Land-plant organic matter is usually rich in woody tissues and hence has higher Rock-Eval oxygen indices and lower hydrogen indices than is found in more lipid-rich marine matter from algal production. Comparison of the hydrogen and oxygen indices of Hauterivian-Barremian, Aptian-Albian, and Cenomanian samples from Leg 103 shows two trends (Fig. 2). First, black shales generally have higher hydrogen indices and lower oxygen indices than the interbedded organic-carbon-lean strata have. Second, black shales become progressively more hydrogen-rich from Neocomian to Cenomanian deposits. These two trends suggest that these Galicia margin black shales in general contain larger proportions of marine-derived organic mat- ter than do the interbedded low-carbon layers and that the proportion of marine-derived material increases progressively from the Hauterivian to Cenomanian. As described in the site chapters (Boillot, Winterer, et al., 1987), the $\mathrm{T}_{\max }$ values are generally typical of immature organic matter in all of these sedimentary rocks.

\section{Extractable Alkanes, Alkanoic Acids, and Alkanols}

Concentrations of extractable geolipids are listed in Table 2 in terms of $\mu \mathrm{g} / \mathrm{g}$ dry sample and $\mu \mathrm{g} / \mathrm{g}$ organic carbon in that sample. In comparison to samples of similar ages and sediment types from Site 603 on the Hatteras Rise, the absolute concentrations of $n$-alkanes and $n$-alkanols in these rocks are similar to those found in the western North Atlantic (Dunham et al:, 1987). Concentrations of $n$-alkanoic acids, however, are generally lower in these eastern margin samples than in the Site 603 rocks, perhaps reflecting more diagenetic reworking of the organic matter in the eastern location, inasmuch as fatty acids are more sensitive to such losses than are the other classes of geolipids (cf. Keswani et al., 1984). The Cenomanian samples from Hole 641A have notably higher absolute concentrations of $n$-alkanes than the other Leg 103 samples and contain more of these hydrocarbons than the Cenomanian samples from Site 603. As seen in the Rock-Eval data (Fig. 2) and C/N ratios (Table 1), the Cenomanian samples at Hole $641 \mathrm{C}$ contain the greatest proportion of marine-type organic matter of any of the rocks surveyed in this study, and their geolipid contents evidently reflect this factor.

The concentrations of geolipids expressed relative to the organic carbon contents of the rocks are low and are similar to the relative concentrations found in Cretaceous samples from Site 603 (Dunham et al., 1987). Black shales, in particular, are lean in relative proportions of extractable geolipids. This low amount of available hydrocarbons is consistent with the low thermal maturity of the samples as given by the Rock-Eval data (Boillot, Winterer, et al., 1987; Stein et al., this volume).

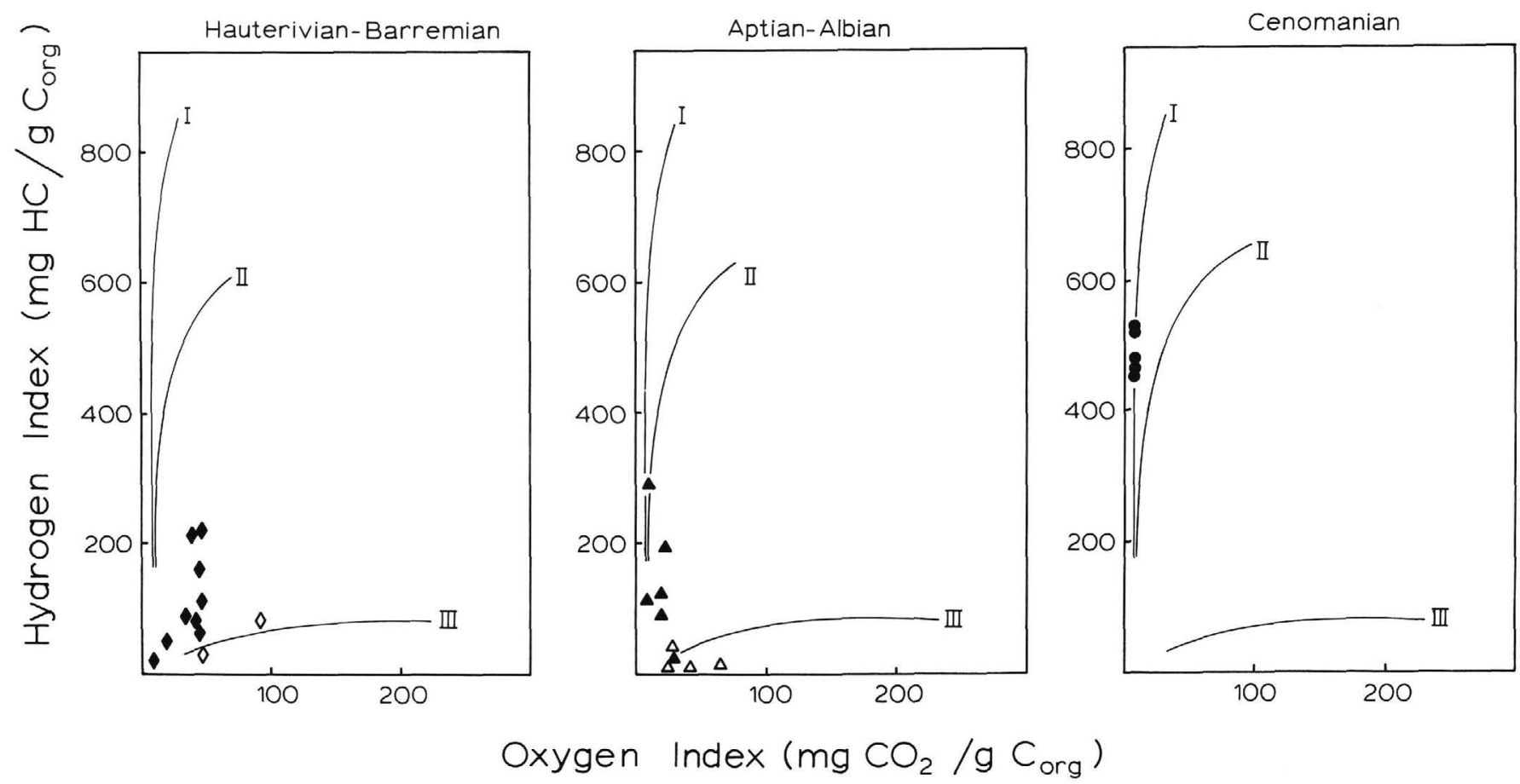

Figure 2. Comparison of Rock-Eval analyses from the three episodes of black shale deposition on the Galicia margin. Solid symbols represent data from black shales samples; open symbols are from organic-carbon-poor samples. 
Table 2. Extractable geolipids from Cretaceous Leg 103 samples.

\begin{tabular}{|c|c|c|c|c|c|c|c|c|c|c|c|}
\hline \multirow[b]{2}{*}{ Sample } & \multirow[b]{2}{*}{$\begin{array}{l}C_{\text {org }} \\
(\%)\end{array}$} & \multicolumn{4}{|c|}{ Alkanes } & \multicolumn{3}{|c|}{ Alkanoic acids } & \multicolumn{3}{|c|}{ Alkanols } \\
\hline & & $\begin{array}{c}\text { Rock } \\
(\mu \mathrm{g} / \mathrm{g})\end{array}$ & $\begin{array}{c}\mathrm{C}_{\mathrm{org}} \\
(\mu \mathrm{g} / \mathrm{g})\end{array}$ & $\mathrm{Pr} / \mathrm{Ph}^{\mathrm{a}}$ & Long/short ${ }^{\mathrm{b}}$ & $\begin{array}{c}\text { Rock } \\
(\mu \mathrm{g} / \mathrm{g})\end{array}$ & $\begin{array}{c}\mathrm{C}_{\mathrm{org}} \\
(\mu \mathrm{g} / \mathrm{g})\end{array}$ & Long/short ${ }^{b}$ & $\begin{array}{c}\text { Rock } \\
(\mu \mathrm{g} / \mathrm{g})\end{array}$ & $\begin{array}{c}\mathrm{C}_{\mathrm{org}} \\
(\mu \mathrm{g} / \mathrm{g})\end{array}$ & Long/short ${ }^{\mathrm{b}}$ \\
\hline \multicolumn{12}{|l|}{ Hauterivian } \\
\hline $638 \mathrm{~B}-35 \mathrm{R}-4,86-91 \mathrm{~cm}$ & 3.00 & 1.77 & 59 & 0.89 & 9.26 & 309 & 1.08 & 13.53 & 451 & 51.63 & \\
\hline 26R-1, $14-19 \mathrm{~cm}$ & 1.46 & 1.61 & 110 & 1.22 & 0.59 & 4.87 & 334 & 0.49 & 9.34 & 640 & 33.64 \\
\hline \multicolumn{12}{|l|}{ Barremian } \\
\hline $638 \mathrm{~B}-23 \mathrm{R}-3,20-26 \mathrm{~cm}$ & 2.39 & 1.69 & 71 & 1.32 & 1.70 & 6.53 & 273 & 0.65 & 9.20 & 385 & 22.62 \\
\hline $23 \mathrm{R}-2,139-145 \mathrm{~cm}$ & 0.16 & 0.54 & 337 & 1.14 & 1.64 & 1.61 & 1006 & 0.29 & 10.11 & 6319 & 49.57 \\
\hline $23 \mathrm{R}-2,19-25 \mathrm{~cm}$ & 2.03 & 2.03 & 100 & 1.46 & 0.50 & 8.52 & 420 & 0.62 & 9.31 & 459 & 17.05 \\
\hline \multicolumn{12}{|l|}{ Albian } \\
\hline $641 \mathrm{C}-2 \mathrm{R}-5,57-60 \mathrm{~cm}$ & 0.15 & 0.98 & 653 & 0.76 & 0.49 & 2.66 & 1773 & 0.39 & 11.43 & 7620 & 32.58 \\
\hline $2 \mathrm{R}-4,3-6 \mathrm{~cm}$ & 4.38 & 2.03 & 46 & 0.80 & 0.61 & 3.96 & 90 & 0.54 & 8.94 & 204 & 25.59 \\
\hline $1 \mathrm{R}-2,68-72 \mathrm{~cm}$ & 4.90 & 2.35 & 48 & 1.41 & 0.64 & 4.21 & 86 & 0.62 & 9.86 & 201 & 23.65 \\
\hline $1 \mathrm{R}-2,49-52 \mathrm{~cm}$ & 3.63 & 1.16 & 32 & 0.92 & 1.37 & 3.54 & 98 & 1.36 & 3.12 & 86 & 6.74 \\
\hline $1 \mathrm{R}-1,20-24 \mathrm{~cm}$ & 1.18 & 0.90 & 76 & 0.66 & 0.77 & 1.99 & 169 & 0.73 & 11.70 & 992 & 23.05 \\
\hline \multicolumn{12}{|l|}{ Cenomanian } \\
\hline $641 \mathrm{~A}-6 \mathrm{X}, \mathrm{CC}(31-34 \mathrm{~cm})$ & 0.25 & 8.57 & 3428 & 0.55 & 0.08 & 2.96 & 1184 & 0.34 & 14.64 & 5856 & 50.50 \\
\hline $6 \mathrm{X}, \mathrm{CC}(3-6 \mathrm{~cm})$ & 10.34 & 22.33 & 216 & 0.37 & 0.24 & 7.39 & 71 & 0.40 & 21.60 & 209 & 17.10 \\
\hline $6 \mathrm{X}-7,21-24 \mathrm{~cm}$ & 0.11 & 9.30 & 8455 & 0.46 & 0.05 & 2.29 & 2082 & 0.13 & 4.81 & 4373 & 51.57 \\
\hline
\end{tabular}

\footnotetext{
${ }^{a} \mathrm{Pr} / \mathrm{Ph}=$ ratio of concentrations of pristane and phytane.

${ }^{b}$ Long/short $=$ ratio of concentrations of selected straight-carbon-chain components representative of continental and marine origins, respectively. For $n$-alkanes, the ratio is $\left(\mathrm{C}_{27}+\mathrm{C}_{29}+\mathrm{C}_{31}\right) /\left(\mathrm{C}_{15}+\mathrm{C}_{17}+\mathrm{C}_{19}\right)$; for $n$-alkanoic acids and $n$-alkanols, it is $\left(\mathrm{C}_{24}+\mathrm{C}_{26}+\mathrm{C}_{28}\right) /\left(\mathrm{C}_{14}+\mathrm{C}_{16}+\mathrm{C}_{18}\right)$.
}

Included in Table 2 are ratios of geolipid components that summarize some aspects of the molecular distributions present in these extractable materials. The isoprenoid hydrocarbons pristane and phytane are at concentrations nearly the same as the closely eluting $\mathrm{C}_{17}$ and $\mathrm{C}_{18} n$-alkanes. Ratios of pristane to phytane vary between 0.37 and 1.46 , showing no relationship to sample lithology, organic carbon content, $\delta^{13} \mathrm{C}$ value, or RockEval indices. The lowest pristane/phytane ratios are found in Cenomanian samples, perhaps recording greater amounts of methanogenic bacterial activity during the deposition of these younger sediments (Risatti et al., 1984; Dunham et al., 1987). Ratios of long-chain-length components of the $n$-alkane, $n$-alkanoic acid, and $n$-alkanol fractions to the short-chain-length components of these sample extracts are given as rough indicators of land-plant wax contributions relative to lipid inputs from aquatic sources (cf. Simoneit, 1978). Most of the long/ short ratios of the $n$-alkane and $n$-alkanoic fractions are low, suggesting a predominance of aquatic lipids, but the $n$-alkanol long/short ratios are consistently much larger, giving a contradictory, terrigenous source indication for these geolipid components. The conflict in geolipid source signals suggests that more than one origin exists for the extractable matter present in these samples.

Comparisons of the distributions of individual $n$-alkanes, $n$ alkanoic acids, and $n$-alkanols (Figs. 3 through 5 ) also imply that several sources have indeed been involved in constituting the geolipid compositions of these Cretaceous rocks. Distributions of $n$-alkanes are generally dominated by components in the $C_{15}$ to $C_{21}$ range. These hydrocarbons do not display the strong odd-over-even chain-length predominance typically found in organisms. In fact, even-carbon-numbered $n$-alkanes are the most abundant compound in six of the 10 distributions. Such absence of odd-over-even predominance suggests these hydrocarbons arise from diagenetically altered material (Simoneit, 1986), and they may represent recycled detrital organic matter eroded from continental sources. Stein et al. (this volume) report the occurrence of secondary vitrinites with higher reflectance values, which supports the presence of redeposited, older organic matter in these rocks. The presence of continental material is further implied in the Hauterivian and Barremian examples shown in Figure 3 by significant proportions of longer chainlength $n$-alkanes having stronger odd-over-even preferences. These hydrocarbons, in the $\mathrm{C}_{27}$ to $\mathrm{C}_{33}$ range, are indicative of the waxy coatings of land plants (Eglinton and Hamilton, 1963; Simoneit, $1978,1986)$. In contrast, the Cenomanian $n$-alkane distributions contain very small proportions of these longer chain-length materials. Because the concentrations of hydrocarbons are significantly higher for these samples (Table 2), the diminished proportions probably result from dilution by large amounts of the shorter chain-length components. Although land-derived $n$-alkanes are present in all of these Leg 103 distributions, their contributions are generally not as important as those reported from western North Atlantic Sites 391, 534, and 603 (Deroo et al., 1978; Erdman and Schorno, 1978; Stuermer and Simoneit, 1978; Herbin et al., 1983; Dunham et al., 1987; Herbin et al., 1987; Rullkötter et al., 1987; Joyce and Van Vleet, 1987), where downslope transport of sediments from shallower to deeper depositional areas is believed to have been important (Robertson and Bliefnick, 1983; Meyers, 1987; Wise and van Hinte, 1987).

Distributions of extractable $n$-alkanoic acids are consistently dominated by the $\mathrm{C}_{16}$ acid (Fig. 4), which is a ubiquitous component of all biota. An obvious biotic character to the alkanoic acid distributions of these samples is further imparted by strong even-over-odd chain-length predominances. This well-preserved indication of the biological origin of these acids contrasts with the altered nature of the $n$-alkanes, a class of organic compounds that is considered significantly less susceptible to diagenetic alteration than are alkanoic acids. Long-chain acids indicative of land plant waxes $\left(\mathrm{C}_{24}, \mathrm{C}_{26}, \mathrm{C}_{28}\right.$, and $\left.\mathrm{C}_{30}\right)$ are present in all the distributions, but at lower proportions than those found in black shales from the Blake-Bahama and Hatteras Formations at sites in the western Atlantic (Cardoso et al., 1978; Dunham et al., 1987). The difference in degree of preserved biological character between the $n$-alkanoic acid fractions and the less degradable $n$-alkane fractions suggests that the bulk of the fatty acid contents of these rocks is secondary, being derived from microbial populations that participated in the degradation of organic substances that were photosynthetically produced by aquatic and continental flora. This degradation most likely took place during and early after sediment deposition, and it appears to break down shorter-chain-length geolipid components preferentially over the longer molecules (Matsuda and Koyama, 1977; Giger et al., 1980).

The $n$-alkanol distributions (Fig. 5) are dominated by three components. The $C_{28}$ and $C_{30} n$-alkanols have been interpreted to be indicators of terrigenous geolipids in marine sediments 


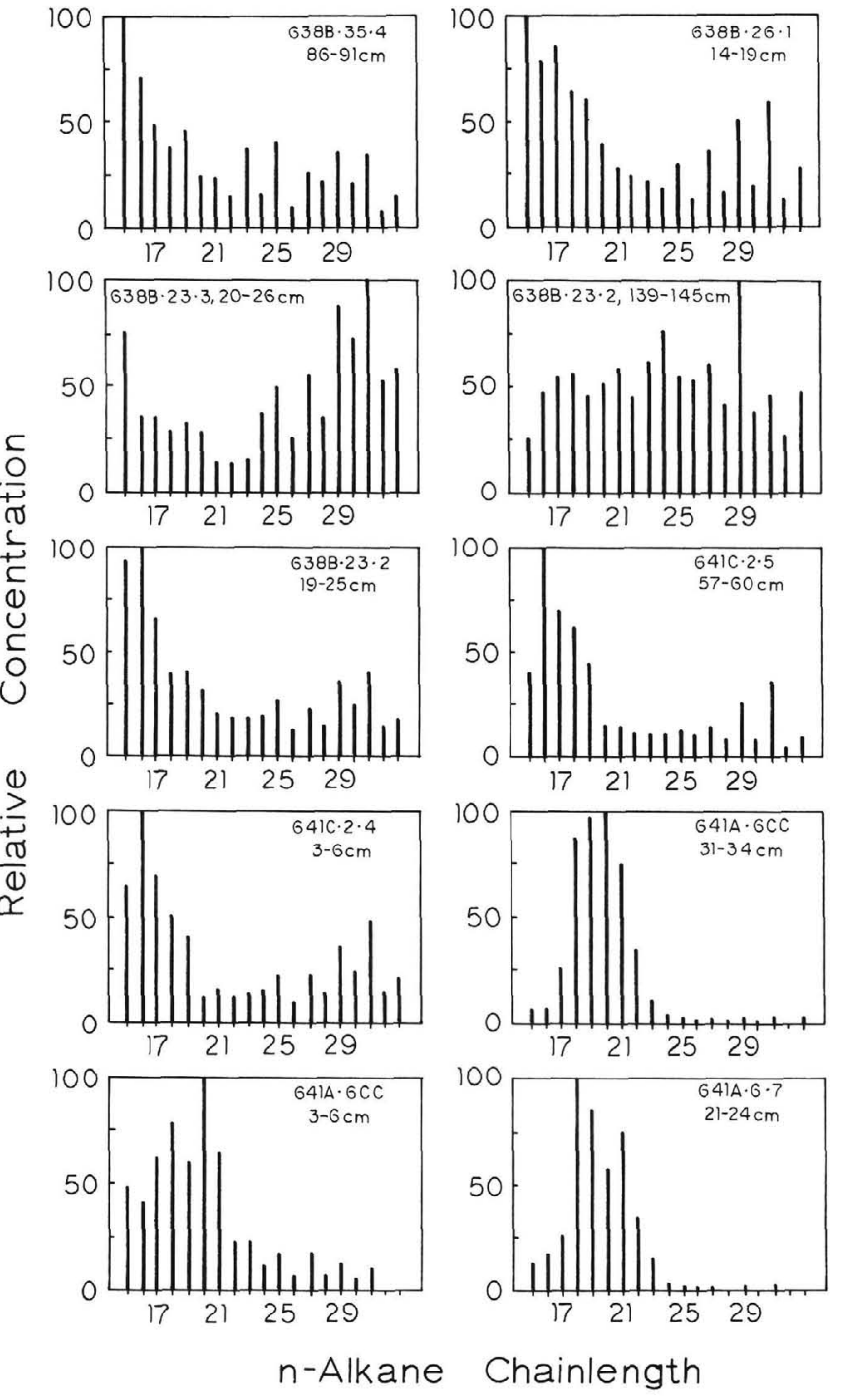

Figure 3. Distributions of $n$-alkanes extracted from selected Leg 103 samples. See Table 1 for descriptions of these samples.

and rocks (Brassell et al., 1982). These long-chain-length alcohols are especially dominant in the black shale in Samples 103638B-26R-1, 14-19 cm (Hauterivian), 103-641C-2R-4, 3-6 cm (Albian), and 103-641A-6X, CC (3-6 cm) (Cenomanian). The most abundant $n$-alkanol in eight of the 10 samples in Figure 5 is $\mathrm{C}_{22}$, which has been postulated to arise from microbial processing of sediment organic matter (Cranwell, 1981; Keswani et al., 1984), a possibility consistent with the $n$-alkanoic acid data. Like the $n$-acids, the even-over-odd carbon-chain-length predominance of these $n$-alkanols is high, indicating good preservation of the biological character of this geolipid fraction. Although generally less susceptible to degradation than $n$-alkanoic acids, these straight-chain alcohols are considered less likely to be preserved than $n$-alkanes are. Because the $n$-alkane fractions of these Leg 103 samples display evidence for their microbial alteration, it is likely the $n$-alkanol distributions reflect a combination of degradation (loss of shorter components, production of $\mathrm{C}_{22}$ ) and retention of originally deposited components (enhanced importance of $\mathrm{C}_{28}$ and $\mathrm{C}_{30}$ ).

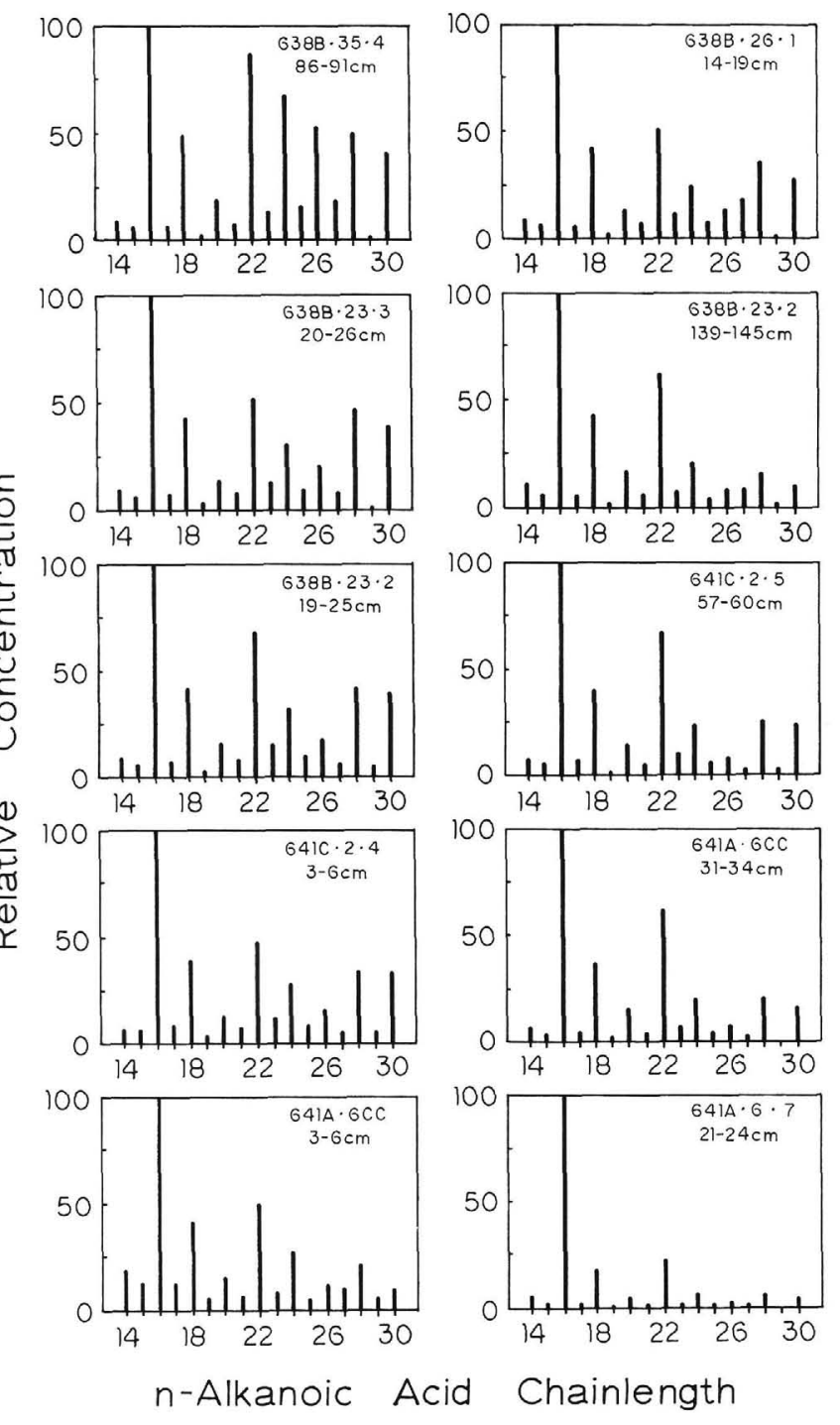

Figure 4. Distributions of $n$-alkanoic acids extracted from selected Leg 103 samples. See Table 1 for descriptions of these samples.

\section{Paleoceanographic Implications}

The amount and the geochemical character of organic matter contained within black shales and adjacent organic-carbonpoor rocks provide information about the paleoceanographic conditions leading to these contrasting types of deposits. Findings of black shales at a number of DSDP sites in the North Atlantic show that these atypical sediments accumulated in episodes generally restricted to Neocomian, Aptian-Albian, CenomanianTuronian, and Coniacian ages (e.g., Arthur and Schlanger, 1979; Tucholke and Vogt, 1979; Thierstein, 1979; de Graciansky et al., 1981; Weissert, 1981; Waples, 1983; Stein et al., 1986). Possible explanations for these depositional episodes combine the effects of sea-level changes, changes in continental climates, variations in the availability of dissolved nutrients, and changes in the shapes of ocean basins to create periods of either middle or bottom-water anoxia in the Mesozoic North Atlantic Ocean (e.g., de Graciansky et al., 1982; Summerhayes and Masran, 1983; Katz and Pheifer, 1986; Arthur and Dean, 1986). The black shales encountered during ODP Leg 103 drilling on the Galicia 

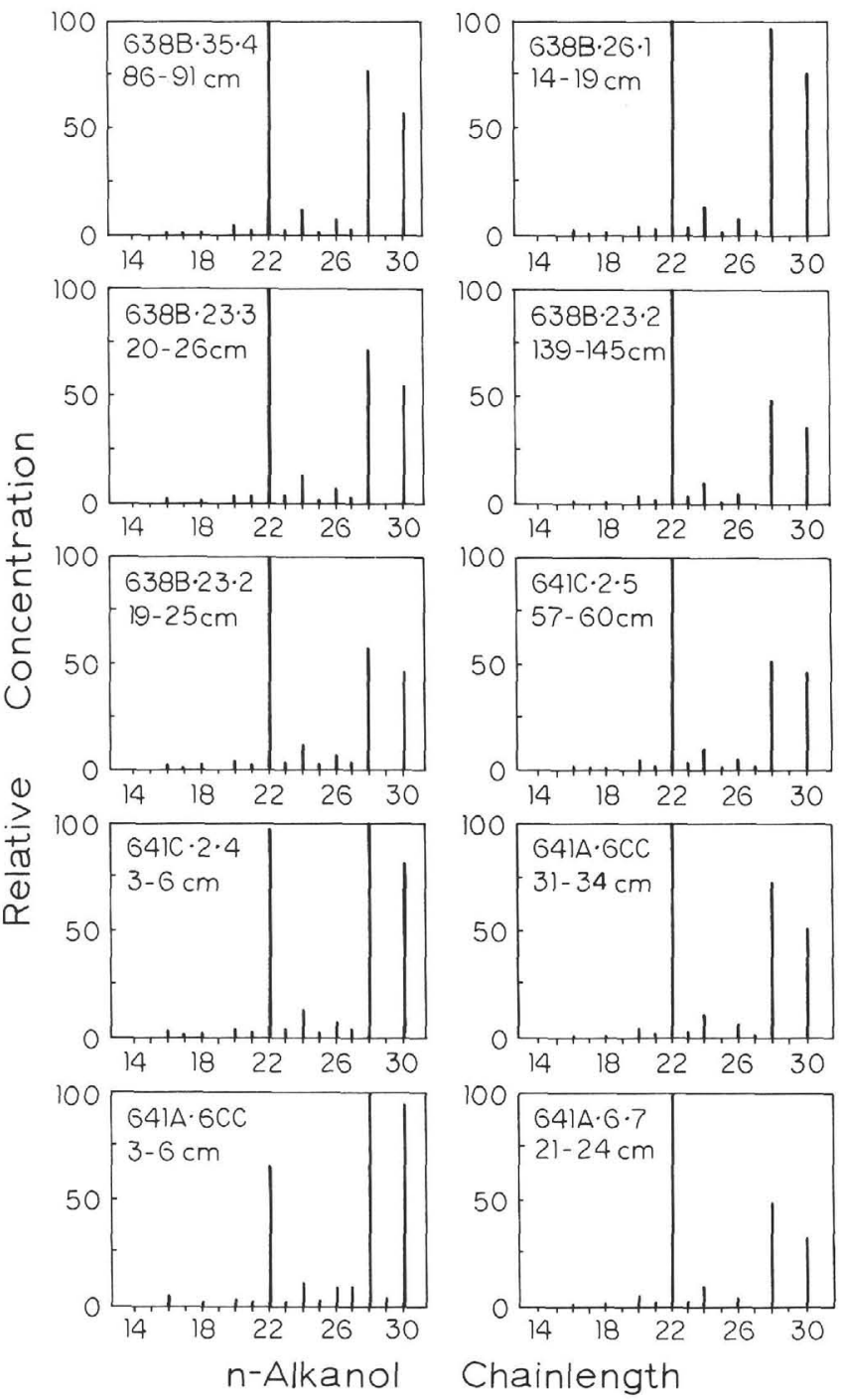

Figure 5. Distributions of $n$-alkanols extracted from selected Leg 103 samples. See Table 1 for descriptions of these samples.

margin are less dramatically enriched in organic matter than those from many other parts of the Atlantic Ocean, yet they become important by providing the longest record of depositional history from a single area of the eastern part of the North Atlantic.

The organic matter present in the Neocomian black shales obtained from Hole 638B is a mixture of terrigenous material and of poorly preserved marine material. These characteristics imply that during this syn-rift stage of development of the Galicia margin, abundant land-derived organic matter accompanied the turbidities, which are found commonly interspersed in the predominantly pelagic carbonate mode of sedimentation. Furthermore, the waters of this young basin were oxygenated, in agreement with bioturbation found commonly in the carbonates (Boillot et al., 1985) which resulted in poor preservation, especially of the marine components of the organic matter. $\mathrm{Ma}$ rine productivity was probably not high.

Aptian-Albian black shales are generally richer in organic carbon content than their Neocomian counterparts, at least partly because they contain little or no carbonate material that can dilute the carbon concentrations. The type of organic matter present in these middle Cretaceous strata is similar to that found in the Neocomian rocks, although slightly richer in its marine proportion. Conditions leading to accumulations of black shale were probably also similar-an oxygenated, turbiditic environment receiving land-derived materials from the erosion of immature coastal areas.

The well-developed black shale occurrence in the abbreviated Cenomanian-Turonian section of Hole 641A required exceptional paleoceanographic conditions for its formation. A period of high productivity, a greatly intensified and expanded oxygenminimum zone, or deep-water anoxia have been discussed as possibilities (e.g., de Graciansky et al., 1984; Arthur et al., 1986; Herbin et al., 1986). Enhanced proportions of marine organic matter and diminished sediment-accumulation rates are two features common to Cenomanian-Turonian deposits in the Atlantic (Stein, 1986; Stein et al., 1986); both are consistent with the section from Hole 641A. The Leg 103 results appear to fit into the ocean-wide Cenomanian-Turonian puzzle. Micropaleontological data show that the oxygen-minimum zone was well developed and reached higher onto the margin of the eastern North Atlantic Ocean (Hart and Ball, 1986), yet the Cenomanian/Turonian Boundary Event remains the best documented candidate for a basin-wide, bottom-water anoxic period in the geological record contained in the seafloor. At Hole 641 A, the abbreviated Cenomanian-Turonian section argues against downslope redeposition, and the concentrations of organic carbon, although elevated, do not indicate a time of greatly enhanced marine productivity, as is recorded in sediments from Site 367 off northwestern Africa (e.g., Herbin et al., 1986). Enhanced preservation of the mixture of marine and continental organic matter found in rocks from Hole 641A probably resulted from a period of deep-water anoxia (de Graciansky et al., 1984; Stein, 1986).

None of the younger rocks and sediments surveyed in this study is rich in organic carbon (Table 1), indicating that from the Coniacian to the present this part of the Atlantic Ocean did not have the combination of highly productive waters, contributions of continental material, rapid sedimentation, and/or anoxia conducive for accumulation of high concentrations of organic matter. Gradual widening of this ocean evidently achieved near-modern conditions of water circulation by Coniacian times on the Galician margin.

\section{SUMMARY}

1. Three episodes of "black shale" deposition are represented in rocks obtained by drilling at Leg 103 holes on the Galicia margin: Hauterivian-Barremian, Aptian-Albian, and Cenomanian-Turonian.

2. The organic matter contained within the black shales and their adjacent organic-carbon-poor strata is a mixture of continental and marine material, displaying varying amounts of microbial reworking.

3. Downslope transport and redeposition of sediments and entrained organic matter from shallower, nearshore or coastal sites was important to the accumulation of the Hauterivian-Barremian and Aptian-Albian episodes of black shales.

4. Deep-water anoxia appears to have contributed to the deposition of organic-carbon-rich sediments in the short Cenomanian section in Hole 641A.

5. The organic matter in these Galicia margin black shales is relatively lean in extractable geolipids and is geothermally immature, reflecting a history of low heat flow on this margin.

\section{ACKNOWLEDGMENTS}

We thank the Ocean Drilling Program, funded by the National Science Foundation and IPOD countries, for providing the opportunity for K.W.D. to participate in Leg 103 and for making samples available to us. Carbon isotope analyses were performed under the direction of $\mathrm{K}$. C. Lohmann. Financial support was provided by a grant from JOI-USSAC. This chapter was reviewed by E. Van Vleet and R. Stein. 


\section{REFERENCES}

Anderson, T. F., and Arthur, M. A., 1983. Stable isotopes of oxygen and carbon and their application to sedimentologic and paleoenvironmental problems. In Arthur, M. A., Anderson, T. F., Kaplan, I. R., Land, L. S., and Veizer, J., Stable Isotopes in Marine Geology: SEPM Short Course, 10:1-1-1-151.

Arthur, M. A., and Dean, W. E., 1986. Cretaceous paleoceanography of the western North Atlantic Ocean. In Vogt, P. R., and Tucholke, B. E. (Eds.), The Geology of North America (Vol. M): Geol. Soc. Am. DNAG Ser., 617-630.

Arthur, M. A., Dean, W. E., and Stow, D.A.V., 1984. Models for the deposition of Mesozoic-Cenozoic fine-grained organic-carbon-rich sediments in the deep sea. In Stow, D.A.V., and Piper, D.J.W. (Eds.), Fine-grained Sediments: Deep-water Processes and Facies: Geol. Soc. Spec. Publ. London, 15:527-560.

Arthur, M. A., and Schlanger, S. O., 1979. Cretaceous "oceanic anoxic events" as causal factors in development of reef-reservoired giant oil fields. AAPG Bull., 63:870-885.

Arthur, M. A., Schlanger, S. O., and Jenkyns, H. C., 1986. The Cenomanian-Turonian Oceanic Anoxic Event, II. Paleoceanographic controls on organic matter production and preservation. In Brooks, J., and Fleet, A. (Eds.), Marine Petroleum Source Rocks: Oxford (Blackwell), 401-420.

Boillot, G., Winterer, E. L., Meyer, A. W., Applegate, J., Baltuck, M., Bergen, J. A., Comas, M., Davies, T. A., Dunham, K., Evans, C. A., Girardeau, J., Goldberg, D., Haggerty, J., Jansa, L. F., Johnson, J. A., Kasahara, J., Loreau, J.-P., Luna, E., Moullade, M., Ogg, J., Sarti, M., Thurow, J., and Williamson, M. W., 1985. Evolution of a passive margin. Nature, 317:115-116.

Boillot, G., Winterer, E. L., et al., 1987. Proc. ODP, Init. Repts., 103: College Station, TX (Ocean Drilling Program)

Brassell, S. C., Eglinton, G., and Maxwell, J. R., 1982. Preliminary lipid analyses of two Quaternary sediments from the Middle America Trench, southern Mexico transect, Deep Sea Drilling Project Leg 66. In Watkins, J. S., Moore, J. C., et al., Init. Repts. DSDP, 66: Washington (U.S. Govt. Printing Office), 557-580.

Cardoso, J. N., Wardroper, A.M.K., Watts, C. D., Barnes, P. J., Maxwell, J. R., Eglinton, G., Mound, D. G., and Speers, G. C., 1978. Preliminary organic geochemistry analyses; Site 391, Leg 44 of the Deep Sea Drilling Project. In Benson, W. E., Sheridan, R. E., et al., Init. Repts. DSDP, 44: Washington (U.S. Govt. Printing Office), 617-623.

Cranwell, P. A., 1981. Diagenesis of free and bound lipids in terrestrial detritus deposited in a lacustrine sediment. Org. Geochem., 3:7989.

Dean, W. E., Arthur, M. A., and Claypool, G. E., 1986. Depletion of ${ }^{13} \mathrm{C}$ in Cretaceous marine organic matter: source, diagenetic, or environmental signal? Mar. Geol., 70:119-157.

de Graciansky, P. C., Bourbon, M., Lemoine, M., and Sigal, L., 1981. The sedimentary record of mid-Cretaceous events in the western Tethys and central Atlantic Oceans and their continental margins. Eclogae Geol. Helv. 47:353-367.

de Graciansky, P. C., Brosse, E., Deroo, G., Herbin, J.-P., Montadert, L., Müller, C., Sigal, J., and Schaff, A., 1982. Les formations d'âge Crétacé de l'Atlantique Nord et leur matière organique: paléogéographie et milieux de dépôt. Rev. Inst. Fr. Pet., 37:275-337.

de Graciansky, P. C., Deroo, G., Herbin, J. P., Montadert, L., Müller, C., Schaff, A., and Sigal, J., 1984. Ocean-wide stagnation episode in the Late Cretaceous. Nature, 308:346-349.

Deroo, G., Herbin, J. P., Roucache, J. R., Tissot, B., Albrecht, P., and Dastillung, M., 1978. Organic geochemistry of some Cretaceous claystones from Site 391, Leg 44, western North Atlantic. In Benson, W. E., Sheridan, R. E., et al., Init. Repts. DSDP, 44: Washington (U.S. Govt. Printing Office), 593-603.

Dunham, K. W., Meyers, P. A., and Dunham, P. L., 1987. Organic geochemical comparison of Cretaceous black shales and adjacent strata from Deep Sea Drilling Project Site 603, outer Hatteras Rise. In van Hinte, J. E., Wise, S. W., Jr., et al., Init. Repts. DSDP, 93: Washington (U.S. Govt. Printing Office), 1195-1210.

Eglinton, G., and Hamilton, R. J., 1963. The distribution of $n$-alkanes. In Swain, T. (Ed.), Chemical Plant Taxonomy: New York (Academic Press), 187-217.
Emeis, K.-C., and Kvenvolden, K. A., 1986. Shipboard Organic Geochemistry on JOIDES Resolution. Ocean Drilling Program Tech. Note, 7.

Erdman, J. G., and Schorno, K. S., 1978. Geochemistry of carbon: Deep Sea Drilling Project Leg 44. In Benson, W. E., Sheridan, R. E., et al., Init. Repts. DSDP, 44: Washington (U.S. Govt. Printing Office), 605-615.

1979a. Geochemistry of carbon: Deep Sea Drilling Project, Legs 47A and 47B. In Sibuet, J.-C., Ryan, W.B.F., et al., Init. Repts. DSDP, 47, Pt. 2: Washington (U.S. Govt. Printing Office), 553-560.

1979b. Geochemistry of carbon: Deep Sea Drilling Project Leg 48. In Montadert, L., Roberts, D. G., et al., Init. Repts. DSDP, 48: Washington (U.S. Govt. Printing Office), 947-950.

Gaskell, S. J., Morris, R. J., Eglinton, G., and Calvert, S. E., 1975. The geochemistry of a recent marine sediment off northwest Africa-an assessment of source of input and early diagenesis. Deep Sea Res. Part A, 22:777-789.

Giger, W., Schaffner, C., and Wakeham, S. G., 1980. Aliphatic and olefinic hydrocarbons in recent sediments of Greifensee, Switzerland. Geochim. Cosmochim. Acta, 44:119-129.

Hart, M. B., and Ball, K. C., 1986. Late Cretaceous anoxic events, sealevel changes and the evolution of the planktonic foraminifera. In Summerhayes, C. P., and Shackleton, N. J. (Eds.), North Atlantic Paleoceanography: Geol. Soc. Spec. Publ. London, 21:67-78.

Herbin, J. P., Deroo, G., and Roucaché, J., 1983. Organic geochemistry in the Mesozoic and Cenozoic formations of Site 534, Leg 76, BlakeBahama Basin, and comparison with Site 391, Leg 44. In Sheridan, R. E., Gradstein, F. M., et al., Init. Repts. DSDP, 76: Washington (U.S. Govt. Printing Office), 481-493.

Herbin, J. P., Masure, E., and Roucache, J., 1987. Cretaceous formations from the lower continental rise off Cape Hatteras: organic geochemistry, dinoflagellate cysts, and the Cenomanian/Turonian Boundary Event at Sites 603 (Leg 93) and 105 (Leg 11). In van Hinte, J. E., Wise, S. W., Jr., et al., Init. Repts. DSDP, 93: Washington (U.S. Govt. Printing Office), 1139-1162.

Herbin, J. P., Mondadert, L., Müller, C., Gomez, R., Thurow, J., and Weidmann, J., 1986. Organic-rich sedimentation at the Cenomanian-Turonian boundary in oceanic and coastal basins in the North Atlantic and Tethys. In Summerhayes, C. P., and Shackleton, N. J. (Eds.), North Atlantic Paleoceanography: Geol. Soc. Spec. Publ. London, 21:389-442.

Jansa, L. F., Enos, P., Tucholke, B. E., Gradstein, F. M., and Sheridan, R. E., 1979. Mesozoic-Cenozoic sedimentary formations of the North American Basin; western North Atlantic. In Talwani, M., Hay, W. and Ryan, W.B.F. (Eds.), Deep Drilling Results in the Atlantic Ocean: Continental Margins and Paleoenvironment: Am. Geophys. Union, Maurice Ewing Ser., 3:1-57.

Jansa, L., Gardner, J. V., and Dean, W. E., 1978. Mesozoic sequences of the central North Atlantic. In Lancelot, Y., Seibold, E., et al., Init. Repts. DSDP, 41: Washington (U.S. Govt. Printing Office), 991-1031.

Joyce, R. M., and Van Vleet, E. S., 1987. A geochemical study of organic-matter-rich Upper Cretaceous claystones from the lower continental rise off North America, Deep Sea Drilling Project Hole 603B. In van Hinte, J. E., Wise, S. W., Jr., et al., Init. Repts. DSDP, 93: Washington (U.S. Govt. Printing Office), 1223-1230.

Katz, B. J., and Pheifer, R. N., 1986. Organic geochemical characteristics of Atlantic Ocean Cretaceous and Jurassic black shales. Mar. Geol., 70:43-66.

Keswani, S. R., Dunham, K. W., and Meyers, P. A., 1984. Organic geochemistry of Late Cenozoic sediments from the subtropical South Atlantic. Mar. Geol., 61:25-42.

Leenheer, M. J., Flessland, K. D., and Meyers, P. A., 1984. Comparison of lipid character of sediments from the Great Lakes and the northwestern Atlantic. Org. Geochem., 7:141-150.

Matsuda, H., and Koyama, T., 1977. Early diagenesis of fatty acids in lacustrine sediments. I. Identification and distribution of fatty acids in Recent sediment from a freshwater lake. Geochim. Cosmochim. Acta, 41:777-783.

McIver, R., 1975. Hydrocarbon occurrences from JOIDES Deep Sea Drilling Project. Proc. World Pet. Congr., 9:269-280. 
Meyers, P. A., 1987. Synthesis of organic geochemical studies, Deep Sea Drilling Project Leg 93, North American continental margin. In van Hinte, J. E., Wise, S. W., Jr., et al., Init. Repts. DSDP, 93: Washington (U.S. Govt. Printing Office), 1333-1342.

Müller, G., and Gastner, M., 1971. The "karbonate-bombe," a simple device for determination of the carbonate content in sediments, soils and other materials. Neues Jahrb. Mineral. Monatsh., 10:466-469.

Peterson, B. J., Howarth, R. W., and Garritt, R. H., 1985. Multiple stable isotopes used to trace the flow of organic matter in estuarine food webs. Science, 227:1361-1363.

Risatti, J. B., Rowland, S. J., Yon, D., and Maxwell, J. R., 1984. Stereochemical studies of acyclic isoprenoids. XII. Lipids of methanogenic bacteria and possible contributions to sediments. Org. Geochem., 6:93-104.

Robertson, A.H.F., and Bliefnick, D. M., 1983. Sedimentology and origin of Lower Cretaceous pelagic carbonates and redeposited clastics, Blake-Bahama Formation, Deep Sea Drilling Project Site 534, western equatorial Atlantic. In Sheridan, R. E., Gradstein, F. M., et al., Init. Repts. DSDP, 76: Washington (U.S. Govt. Printing Office), 795-828.

Rullkötter, J., Mukhopadhyay, P. K., and Welte, D. H., 1987. Geochemistry and petrography of organic matter from Deep Sea Drilling Project Site 603, lower continental rise off Cape Hatteras. In van Hinte, J. E., Wise, S. W., Jr., et al., Init. Repts. DSDP, 93: Washington (U.S. Govt. Printing Office), 1163-1185.

Simoneit, B.R.T., 1978. The organic chemistry of marine sediments. In Riley, J. P., and Chester, R. (Eds.), Chemical Oceanography (Vol. 7): London (Academic Press), 233-311.

1986. Biomarker geochemistry of black shales from Cretaceous oceans: an overview. Mar. Geol., 70:9-41.

Stein, R., 1986. Organic carbon and sedimentation rate-further evidence for anoxic deep-water conditions in the Cenomanian/Turonian Atlantic Ocean. Mar. Geol., 72:199-209.

Stein, R., Rullkötter, J., and Welte, D. H., 1986. Accumulation of organic-carbon-rich sediments in the Late Jurassic and Cretaceous Atlantic Ocean: a synthesis. Chem. Geol., 56:1-32.
Stuermer, D. H., and Simoneit, B.R.T., 1978. Varying sources for the lipids and humic substances at Site 391, Blake-Bahama Basin, Deep Sea Drilling Project Leg 44. In Benson, W. E., Sheridan, R. E., et al., Init. Repts. DSDP, 44: Washington (U.S. Govt. Printing Office), 587-591.

Summerhayes, C. P., and Masran, T. C., 1983. Organic facies of Cretaceous and Jurassic sediments from Deep Sea Drilling Project Site 534 in the Blake-Bahama Basin, western North Atlantic. In Sheridan, R. E., Gradstein, F. M., et al., Init. Repts. DSDP, 76: Washington (U.S. Govt. Printing Office), 469-480.

Thierstein, H. R., 1979. Paleoceanographic implications of organic carbon and carbonate distribution in Mesozoic deep-sea sediments. In Talwani, M., Hay, W., and Ryan, W.B.F. (Eds.), Deep Drilling Results in the Atlantic Ocean: Continental Margins and Paleoenvironment: Am. Geophys. Union, Maurice Ewing Ser., 3:249-274.

Tucholke, B. E., and Vogt, P. R., 1979. Western North Atlantic: sedimentary evolution and aspects of tectonic history. In Tucholke, B. E., Vogt, P. R., et al., Init. Repts. DSDP, 43: Washington (U.S. Govt. Printing Office), 791-825.

Waples, D. W., 1983. Reappraisal of anoxia and organic richness, with emphasis on Cretaceous of North Atlantic. AAPG Bull., 67:963978.

Weissert, H., 1981. The environment of deposition of black shales in the Early Cretaceous: an ongoing controversy. In Warme, J. E., Douglas, R. G., and Winterer, E. L. (Eds.), The Deep Sea Drilling Project: A Decade of Progress: Spec. Publ. Soc. Econ. Paleontol. Mineral., 32:547-560.

Wise, S. W., Jr., and van Hinte, J. E., 1987. Mesozoic-Cenozoic depositional environments revealed by Deep Sea Drilling Project Leg 93 drilling on the continental rise off the eastern United States: cruise summary. In van Hinte, J. E., Wise, S. W., Jr., et al., Init. Repts. DSDP, 93: Washington (U.S. Govt. Printing Office), 1367-1423.

Date of initial receipt: 10 August 1987

Date of acceptance: 13 January 1988

Ms 103B-157 